\title{
Assessment of Entrepreneurial Traits among Undergraduate Students of Clothing, Textile and Interior Decoration
}

\author{
Adetoun Adedotun Amubode ${ }^{1} \&$ Olajide Rahman Goriola ${ }^{2}$ \\ ${ }^{1}$ Department of Home Science and Management, Federal University of Agriculture, Abeokuta, Nigeria \\ ${ }^{2}$ Department of Home Economics, Tai Solarin College of Education, Ijebu-Ode, Nigeria \\ Correspondence: Adetoun Adedotun Amubode, Department of Home Science and Management, Federal \\ University of Agriculture, PMB 2240, Abeokuta, Ogun State, Nigeria. Tel: 234-0807-977-1568. E-mail: \\ amuboto@yahoo.com
}

Received: March 23, 2015 Accepted: May 3, 2015 Online Published: July 30, 2015

doi:10.5539/ijms.v7n4p94 URL: http://dx.doi.org/10.5539/ijms.v7n4p94

\begin{abstract}
The philosophy of Clothing, Textile and Interior Decoration in the department of Home Science and Management is to produce graduates that are adequately equipped with comprehensive theoretical knowledge and practical skills required to succeed in any enterprise within their career. Yearly, thousands of graduates are turned out with no jobs and the few that are self-employed experience multi-facet challenges that inhibits business success and discourage motivation to establish a business. This study assessed the Entrepreneurial Personality Trait of final year students of Clothing, Textile and Interior Decoration prior to business start-up and their future plan after graduation. All the final year students were used for the study. Questionnaire was used to gather the data which was designed using Granger and Sterling Personal Assessment Scale. The result shows that about one-third of the students (32.14\%) have plan to be self- employed after graduation, $14.29 \%$ want to travel abroad, $28.57 \%$ want to further their academic career while $25 \%$ want to secure job in either private or public sector. The average Personality Score of the Students is 74.06 (Mid-to-Lower Range) indicating that the students need to spend more time to develop their entrepreneurial skills so as to succeed in a socio-economic challenging environment.
\end{abstract}

Keywords: entrepreneurship, unemployment, clothing, textile, interior Decoration and undergraduate

\section{Introduction}

Before the advent of colonial government, unemployment was a rare phenomenon in Nigeria, because the people were highly entrepreneurial and productively engaged. This entrepreneurial engagement is prevalent in Yoruba land of western Nigeria, Hausa land of the northern Nigeria, and among the Igbo people of eastern Nigeria; the society encourages communal wealth creation and productive use of human resources, thus forestalling unemployment (Oladele, Akeke, \& Oladunjoye, 2011).

Nigeria became an independent country from British Government in 1960. Unfortunately, it adopted a socio-economic model of development, which was highly defective. "Politically, it adopted Statism as a model of political governance while economically it adopted an import substitution industrialization model" (Benson, 2005). "The statism model ensures that government assumed the dominant role as producer and controller in the economy at the expense of private sector initiatives. The consequence of this model is the creation of an environment in which the Federal government became the major source of patronage and the desire for public office became a matter of life and death. Furthermore, the import substitution industrialization model showed defective in the area of economic growth; it led to a diversion of the country's attention away from any serious exploitation, evaluation and development of its own raw material base; shows lack of capacity to develop indigenous technology needed for supporting indigenous business sector; inability of the nation to engage in the production of producer goods; perpetuation of a state of low -level skills within the indigenous industrial sector; encourages perpetual dependence of the country's economy on foreign entrepreneurs for the solution of its socioeconomic problems and discourages the production and utilization of appropriate grade of scientist, engineers, technicians, craftsmen and other skilled people needed for domestic technological take-off" (Benson, 2005). 
The emergence of administration in Nigeria introduced formal education which enabled people to have the opportunity of being employed in the civil service after graduation. As such, the system destroyed self-reliance, self-employment and entrepreneurial skills of Nigerians as they became permanently dependent on the colonial masters (Nicks, 2008; Raimi \& Adeleke, 2010). This led to massive unemployment and craze in the contemporary times for ready-made jobs, (Oladele, Akeke, \& Oladunjoye, 2011). Consequently, graduating with a good grade or having a certificate is no longer a guarantee to secure job; the unemployment crisis in Nigeria is an indication for students in tertiary institutions to learn to make a living from their passion by embracing entrepreneurship.

\subsection{Unemployment Crises in Nigeria}

The National Bureau of Statistics (NBS) defines unemployment as the proportion of the labour force that is available for work but did not work for at least 39 hours in the week preceding the survey period (Central Bank of Nigeria Annual Report, 2008). The CBN report went further to say that individuals who did not fall into either of these groups, such as retired people and discouraged workers, are not included in the calculation of the labour force. Abiodun (2010) regards unemployment as the proportion of the labour force, expressed in percentage, which is not employed at any given point in time.

Unemployment remains one of the serious problems facing Nigeria and government does not seems to understand the real magnitude of the challenge, it creates the impression that solution is far from view (Ukwu, 2013). The unemployment crisis is as a result of rapid growth in population, rural urban migration, wrong perception of policy makers, lack of employable skills and lack of entrepreneurial training in the curricula of higher institutions (Fnae, Adeniji, \& Adu, 2008; Okafor, 2011; Kakwagh \& Ikwuaba, 2010).

In Nigeria, the analysis of labour statistics indicates that the unemployment rate for university graduates may be around $25 \%$ and that their prospects for being employed have worsened over time. According to the 2006 provisional census figure, Nigeria has a youth population of over 80 million, or $60 \%$ of her total population, of this population, more than $80 \%$ are unemployed while about $10 \%$ are underemployed. Data provided by the National Manpower Board and Federal Bureau of Statistics indicated that only about $10 \%$ of the graduates released into the labour market annually by Nigerian universities and other tertiary institutions are able to get paid employments (Chilee, 2013).

Nigerian University education has grown in leaps and bounds; this is particularly noticeable owing to the emergence of private and state universities in the country which has rapidly increase the turnout of university graduates resulting to severe graduate unemployment (Fnae, Adeniji, \& Adu, 2008). Similarly, Bakare (2011) informs that since early eighties urban unemployment has assumed an alarming dimension and a crisis proportion with millions of able-bodied persons who are willingly to accept jobs at the prevailing wage rates are unable to find placement. Unemployment is a situation where people who are willing and capable of working are unable to find suitable paid employment (Fajana, 2000). Graduate unemployment, therefore, refers to the unemployment among people who have graduated from tertiary institutions and who are qualified to work but do not work at any given point in time (Akinyemi, Ofem, \& Ikuenomore, 2012).

Many students who successfully gained admission to tertiary institutions often have dreams to secure enviable jobs with robust pay, live a comfortable life and financially assist their family after graduation, but few make preparation for the challenges of prevalent unemployment. Thousands of graduates that are turned out every year end up roaming the streets for years without any hope of securing paid employment even after sacrificing one year to serve their fatherland through the National Youth Service Corps (NYSC) scheme (Fnae, Adeniji, \& Adu, 2008). This crisis leads to several social problems such as frustration, depression, hostility, arm robbery, ethnic militia, poverty, sickness and criminal behaviour (Adebajo, 1999; Egbuna, 2001; Fnae, Adeniji, \& Adu, 2008).

While graduates complain of high levels of unemployment, employers, on the other hand, complain that the graduates are poorly prepared and therefore not suitable for the work environment. Certain major characteristics such as, but not limited to, effective problem solving skills, ability to think outside the box, teamwork, focus, drive, charisma, motivation, flexibility, the abilities to initiate, analyse, plan and organise, expected from the graduates are minimum or completely lacking. It is against these backdrops that the graduates are commonly viewed as incompetent (Chilee, 2013).

\subsection{The Vision of Clothing, Textile and Interior Decoration}

The Department of Home Science and Management was established in 1988 at the inception of the University of Agriculture Abeokuta. The department offers a degree programme in Home Science and Management with options in Clothing and Textile, Nutrition and Dietetics, Child Development and Family studies, Home and Furnishing Design and Home Science Extension. With the establishments of the departments of Nutrition and 
Dietetics, the departments now offer three options; these are Clothing, Textile and Interior Decoration, Child Development and Family Studies, and Home Science Extension.

The Department of Home Science and Management trains the students in the above broad area ensuring the production of highly skilled manpower through adoption of effective techniques of instructions, laboratory practical, field demonstration and workshop practice such that our graduates can choose to specialize in any of the relevant discipline.

The study was carried out among final year undergraduate students that enrolled for Clothing, Textiles and Interior Decoration as a career in the Department of Home Science and Management, Federal University of Agriculture, Abeokuta. The Philosophy of this field of study is to produce graduates that are adequately equipped with the comprehensive theoretical knowledge and practical skills required for engaging in productive clothing, textile and Interior Decoration service/product enterprise. The students undergo practical training in an industry for a period of six months with no classroom lectures; the students are expected to put into practical use the knowledge they have learned in the classroom and laboratory. During this period they also acquire new skills and knowledge to match employers' expectations. At the end of the training, the students present a seminar/report of their experiences as a way of stimulating their interest in job creation.

Clothing, textile and interior decoration is housed within the department with the following objectives:

a. To produce graduates geared towards self-employment;

b. To produce graduates with sufficient technical, productive and entrepreneurship skills who will be involved in production, research and entrepreneurship in any aspect of clothing, textiles and Interior Decoration;

c. To produce graduates that are relevant to themselves, the industry and society and who can contribute effectively to national development goals in clothing, textiles and Interior Decoration industries.

\subsection{Entrepreneurship: Gateway to Job Creation}

Understanding entrepreneurship, its rewards and challenges is the first step in considering business ownership; it is an opportunity to act on dreams, become one's own boss, secure financial freedom and share passion with others (Granger \& Sterling, 2012, p. 20).

Entrepreneurship is the creation of a new economic entity centred on a novel product or service or at the very least on which differs significantly from products or services offered elsewhere in the market (Curran \& Stanworth, 1989, p. 12). Anyone that creates a new business can be regarded as an entrepreneur. Aromolaran (1978) describes an entrepreneur as a person who performs the task of combining the different factors necessary for the production of a commodity, having the ability to see and evaluate business opportunities, to be action oriented, highly motivated individual who takes risk to achieve goals, have self-confidence, be task result oriented, risk taker, have leadership status, be original, be creative, innovative and future oriented. This helps an individual in self-examination, especially in identifying, strengths and weaknesses in respect of becoming a successful entrepreneur. Other qualities such as technical knowledge, practical experience in the line of business or product, clarity of decisions, managerial competence, planning, orientation and institution building capabilities should be possessed (Olajire, 2004).

In the mainstream or neoclassical economic theory, the entrepreneur is someone who co-ordinates different factors of production (Deakins \& Freel, 2009, p. 2). However, this role is view as non-important because the entrepreneur is merged with the capitalist employer, the owner manager who has the wealth to enable production to take place. The idea that the entrepreneur has a significant role in economic development has being by writers outside mainstream economic thinking; this has an important contribution with attention focused on Small and Medium Scale Enterprises (SMEs) sector for economic development and job creation (Deakins \& Freel, 2009, p. 3).

There are six important theories of entrepreneurship; these are, Cantillon, Say, Kirtzner, Schumpeter, Knight and Cansson theories of entrepreneurship.

Cantillon was the first to recognise the crucial role of an entrepreneur in economic development which was focused on individual property rights. Cantillon recognises the classes in the society- the land owners, the workers and the entrepreneur; entrepreneurs are the most important of these classes (Deakins \& Freel, 2009, p. 3 ); he viewed entrepreneur as someone who is willing to take risk of bringing different factors of production together (Deakins, 1996, pp. 8-14).

Say also made the entrepreneur the pivot of the economy and a catalyst for economic change and development. The entrepreneur provided a commercial stage in three stages of production- he could be seen as close to the 
traditional mainstream and as someone willing to take risk of bringing different factors of production together (Deakins \& Freel, 2009, p. 3).

For Kirzner, the entrepreneur is someone who is alert to profitable opportunities for exchange; he is alert to opportunities for trade. Recognising the possibilities for exchange enables the entrepreneur to benefit by acting as a middleman who facilities the exchange. He/she is able to identify suppliers and customers and act as the intermediary. There is no necessity to own resources and profit arises out of the intermediary function (Deakins \& Freel, 2009, p. 4).

The possibilities for profitable exchange exist because of imperfect knowledge. The entrepreneur has some additional knowledge which is not possessed by others. This information permits the entrepreneur to take advantage of profitable opportunities (Deakins, 1996). The information is costless-it arises when someone notices an opportunity which might have been available all the time. It might often seem obvious after the service or product has been provided but it still takes someone with additional knowledge to recognise and exploit the opportunity (Deakins \& Freel, 2009, p. 4).

Schumpeter entrepreneur is an innovator. The entrepreneur brings about change through the introduction of new technological processes and products (Deakins \& Freel, 2009, p. 4). For Kirzner any one has the potential to be an entrepreneur and he/she operates within set production constraints. For Schumpeter, only certain extraordinary people have the ability to be entrepreneurs and they bring about extraordinary events.

The Schumpeter entrepreneur changes technological possibilities alter convention through innovative activity and moves production constraints. He/she develops new technology whereas the Kirzner entrepreneur operates opportunities that arise out of new technology. For Schumpeter, large monopolistic firms have distinct advantages over small firms in technological process (Deakins \& Freel, 2009, p. 4).

For Knight, the entrepreneur is an individual who is prepared to undertake uninsurable risk and the reward is profit for bearing uncertainty. The entrepreneur is therefore one who is willing to accept the remaining risk that cannot be transferred through insurance (e.g., insurance against business failure); consequently, the entrepreneur is responsible for his/her own action (Deakins, 1996; Deakins \& Freel, 2009).

Shackle's entrepreneur is someone who is creative and imaginative. Kirzner entrepreneur perceives opportunities while Shackle's imagines opportunities. Everyone potentially has creative ability which is exercised in making choices. Shackle's entrepreneur is creative and original. The act of imagination is important for identifying the potentials of opportunities and creativity is an important element in entrepreneurship process (Deakins \& Freel, 2009).

Casson attempts to synthesis some of these entrepreneurial attributes and concepts. Casson recognises that entrepreneurs will have different skills; these skills will enable the entrepreneur to make judgements and to co-ordinate scare resources. The entrepreneur requires command over resources, so personal wealth is important. Lack of financial capital would be a barrier to successful entrepreneurship (Deakins, 1996, pp. 9-14; Deakins \& Freel, 2009, p. 5).

This study adopts all the entrepreneurial theories because each theory has a unique concept required by an entrepreneur to be successful in a technological dynamic society with multi-facet challenges for sustainable growth and economic advancement of the business and nation.

Ideologies, social, economic consequences, attitudes, values and beliefs combine to either promote or inhibit future entrepreneurial behaviour (Scase \& Goffe, 1980). However in Nigeria despite the poor economic conditions, many entrepreneurs have the initiative to start new ventures but lack the skills, tools and support to succeed. Corruption, economic instability, lack of infrastructure and management capacity, high taxes, wealth transfer, cronyism and legal insecurity all conspire against progress (www.fateusa.org/about.html Nigerian times, 2008).

\subsection{Developing Entrepreneurial Skills}

Entrepreneurship is not just about acquiring technical creative business skills; it is also about the process of developing appropriate social and cultural capital (Coleman, 1997; Bourdieu, 1984). According to Raff, Lovatt, Banks \& O'Connor, (2000), entrepreneurship is the acquisition of a particular set of knowledge, understandings and behaviours which allows person to operate in the cultural field with certain expert; it is a way of conceiving one's identity. 
Entrepreneurship drives innovation and technical change thereby generating economic growth (Schumpeter, 1934). Timmons (1999) defines entrepreneurship as a way of thinking, reasoning and acting, that is opportunity obsessed, holistic in approach and leadership balanced.

Entrepreneurship is a creative process by which new knowledge is converted into products and services (Shane \& Venkataraman, 2000). Entrepreneurs have the ability to be creative with limited resources, ownership of resources is not a mandatory requirement for entrepreneurs to make use of them; ownership of capital is not necessary to provoke entrepreneurship (Saylor, 1987; Kirzner, 1973). This is in line with Kodithuwakku \& Rosa (2002), argued that the best way of observing the true value of entrepreneurship is when resources and opportunities are at most meagre, the greater the possibility of observing entrepreneurial process.

The absence of resources in a poor environment might be considered a chronic almost insurmountable handicap to the ability of the entrepreneur to develop, perceived opportunities of any significant economic value, (Kodithuwakku \& Rosa, 2002). The challenges of business ownership are immense, but the greatest challenge is the objective evaluation of oneself and one's ideas (Granger \& Sterling, 2012).

Various studies have being conducted on the traits of successful and unsuccessful entrepreneurs, however in the world of entrepreneurship, chances of success increases if the prospective entrepreneur has an understanding of who he/she is. Some people have personal attributes needed to be entrepreneurs, others develop the skill and qualities required to succeed while others never succeed in developing these skills and qualities (Granger \& Sterling, 2012). According to Deakins \& Freel (2009), pre-entrepreneurial experiences, personal background, education, employment, attitudes and learning will have influence on nascent (pre-start) entrepreneurs; these experiences will combine to affect the extent to which individual is prepared to recognise and exploit opportunities.

Clothing, textile and Interior Decoration courses/module provide the students with an initial inspiration and opportunity to be self-employed. Various studies have being conducted on entrepreneurship but no study looked into the entrepreneurial skills of the entrepreneurs prior to business start-up. This study aims at assessing the entrepreneurial traits of final year Clothing, Textile and Interior Decoration undergraduate students in becoming their own boss, have financial freedom, create jobs and become employer of labour in an environment of multi-facet challenges.

Entrepreneurship and economic development are linked with innate personality traits of individuals (Deakins, 1996, p. 16). The need for achievement or 'nAch' drives a person to strive for success and individuals who are high achievers will choose a situation characterized by individual responsibility, moderate risk - taking as a function of skill, knowledge of result of decisions, novel instrumental activity and anticipation of future possibilities and entrepreneurship is the vehicle through which the success is attained (McClelland \& Winter, 1969; Spring \& McDade, 2003, p. 5). Miner, Smith \& Bracker (1989) developed Mc Clelland's achievement motivation theory, by developing five motive patterns, which form an overall index of task motivation: self-achievement; risk-taking; feedback of results; personal innovation and planning for the future. Consequently, the entrepreneur should develop personality profile that can lead to distinctive business success (Amubode, 2009).

The environment influences purposeful business systems; principally because the business system inputs derived from the environment consumes the outputs. The environment is characterized by complexity, turbulence, uncertainty, and risk (Olajire, 2004, p. 50); a business environment offers both opportunities and threats, thus there is a vital need for the entrepreneurial seed to be planted in the students as a driving wheel needed to create job for themselves, employ others and reduce the unemployment crisis in the country. Consequently, for this transformation to take place, quality entrepreneurial seed must be planted in a fertile ground of both the entrepreneur and in the business, continuously watered, deeply rooted with adequate supply of entrepreneurial nutrients and strategic marketing that will grow into a mighty, flourishing business tree, with enviable fruits and resistance to challenges (Amubode, 2009).

The keys to initiating entrepreneurship process lie within the individual members of the society and the degree to which a spirit of enterprise exists or can be stimulated (Morrison, 1998). The key question is what triggers the release of this invaluable enterprising spirit? Hofstede (1991) stressed that the spirit of enterprise can be triggered by acknowledging individuality and uniqueness of members of societies who are motivated to act entrepreneurially. Each entrepreneur brings his or her own unique set of personal characteristics to interact with his/her specific host society and business environment. Furthermore, Morrison (1998) informs that entrepreneurs bring intelligence and sound analytical skills to bear on risk management, exhibit strong moral work and business ethics, commitment to lifelong learning through both formal and informal mechanism and extensive use 
of both formal and informal networks.

Recognition of the distinctive contribution of the individual in the process of economic restructuring has ensured that policy makers support entrepreneurship internationally (Pearce, 1980). The triggers of this recognition have usually being born out of adverse economic conditions; however, it has also being a response to a desire to enhance already strong economies.

Perceived self-efficacy is also positively related to the intention of starting one's own business and exploring new opportunities. People with a high level of self-efficacy (that is with high assurance in their capabilities) approach difficult tasks as challenges to be mastered rather than issues to be avoided. They set themselves challenging goals and maintain strong commitments to them (Chan, Gene, Green, \& Crick, 1998). They are persistent even in the face of failure and they maintain an analytical distance that guides effective performance; they also tend to attribute failure to insufficient effort and poor knowledge (Krueger \& Dickson, 1994).

On the other hand, people with a low level of self-efficacy shy away from difficult tasks, which are perceived as personal threats. They have low level of aspiration and commitment to goals they have chosen to pursue, do not maintain any analytical focus and they give up easily. Failure is attributed to external obstacles and personal deficiencies; consequently, they rapidly lose faith in their own capabilities (Chan, Gene, Green, \& Crick, 1998). Reynolds \& White (1997) stated that fear of failure may act as a significant constraint on this process. However, the existence of role models will also affect such process. However, self-efficacy can be enhanced through proper training (Carter \& Jones-Evans, 2000, p. 148). The students should therefore note that fear of ...... is a barrier in business establishment. Therefore, the students should examine their skills objectively; develop self-efficacy and take-up the unemployment crisis as an opportunity for creative innovation and job creation.

Intrinsic Motivation is connected with interest and enjoyment. Intrinsically motivated behaviours are ones in which there is no apparent reward except for the activity itself. On the other hand, intrinsically motivated behaviours refer to behaviours where external motivators play a central role to motivate behaviour e.g. acting to get a reward and not because the task itself is attractive (Amabile, Hill, Hennessey, \& Tighe, 1994; Deci, 1992). Challenge can stimulate a person to an activity where the individual has a good chance, but is not certain to succeed (Amabile et al., 1994).

\section{Method}

The study was carried out among undergraduates' final year students of Clothing, Textiles and Interior Decoration who had received formal and vocational training to be self-employed in their chosen field of study. The total population of the students is 28 and all of them were used for the study. Questionnaire was used to gather the data. The questionnaire was designed to identify the future plan of the students after graduation and to assess the entrepreneurial personality traits of the students. Granger and Sterling (2012), Entrepreneurship Personal Assessment Scale was adopted. The scale consists of 31 statements with a score of 1-4 (Strongly Agree- 4, Agree-3, Disagree-2 and Strongly Disagree- 1). The data was analysed using descriptive statistics- a score between 31 and 80 points is in the mid-to-low range-meaning that the prospective entrepreneur needs to spend more time developing confidence, skills and abilities in certain areas before committing time and money, while a score between 81 and 124 points is in the mid-to-upper range- indicating that the prospective entrepreneur possesses many of the key habits and skills needed to become successful (Granger \& Sterling, 2012, p. 10). A high score indicates that prospective entrepreneur will welcome challenges, set goals, and implement the steps necessary in achieving those goals.

The decision rule for data analysis was based on the Mean Score using the below classification:

31-80 --------------------Mid-to-Lower Range

81-124 ------------------Mid-to-Upper Range 


\section{Result and Discussion}

Table 1. Personal entrepreneurial assessment score of final year clothing textile and interior decoration students

\begin{tabular}{|c|c|c|c|c|}
\hline S/no & STATEMENT & $\begin{array}{l}\text { TOTAL } \\
\text { SCORE }\end{array}$ & $\begin{array}{l}\text { MEAN } \\
\text { SCORE }\end{array}$ & DECISION \\
\hline 1 & I attend the organisational meeting I have scheduled & 94 & 3.36 & Mid- to-Upper Range \\
\hline 2 & I show up for classes and other events on time. & 73 & 2.61 & Mid-to-Low Range \\
\hline 3 & I take responsibility for my college courses and assignment & 94 & 3.36 & Mid- to-Upper Range \\
\hline 4 & I prioritize my list of things to do & 64 & 2.29 & Mid-to-Low Range \\
\hline 5 & I finish my assignment on time & 60 & 2.14 & Mid-to-Low Range \\
\hline 6 & I know how much time I spent on each activity and/or class per week. & 75 & 2.68 & Mid-to-Low Range \\
\hline 7 & I manage my time well in College & 63 & 2.25 & Mid-to-Low Range \\
\hline 8 & I am excited when new opportunities and projects present themselves & 68 & 2.43 & Mid-to-Low Range \\
\hline 9 & I have the ability to make decisions quickly & 61 & 2.18 & Mid-to-Low Range \\
\hline 10 & I make good decisions & 87 & 3.11 & Mid- to-Upper Range \\
\hline 11 & I like working on numerous task at the same time & 53 & 1.89 & Mid-to-Low Range \\
\hline 12 & I enjoy competition & 60 & 2.14 & Mid-to-Low Range \\
\hline 13 & I set goals for myself and meet those goals & 56 & 2.0 & Mid-to-Low Range \\
\hline 14 & I am responsible with my finances & 62 & 2.21 & Mid-to-Low Range \\
\hline 15 & $\begin{array}{l}\text { I am happiest when I am responsible for myself and my own } \\
\text { decisions }\end{array}$ & 93 & 3.32 & Mid- to-Upper Range \\
\hline 16 & I prefer to work in a group setting on a class project rather than alone. & 61 & 2.18 & Mid-to-Low Range \\
\hline 17 & I have the ability to motivate others. & 89 & 3.18 & Mid- to-Upper Range \\
\hline 18 & $\begin{array}{l}\text { I volunteer to take on leadership roles. I enjoy being the one } \\
\text { responsible for organising a project and keeping the project on } \\
\text { schedule. }\end{array}$ & 56 & 2.0 & Mid-to-Low Range \\
\hline 19 & I enjoy new challenges & 56 & 2.0 & Mid-to-Low Range \\
\hline 20 & I am talented at finding new ways to do things & 64 & 2.29 & Mid-to-Low Range \\
\hline 21 & I am intuitive & 79 & 2.82 & Mid-to-Low Range \\
\hline 22 & I enjoy being busy. I don't like to sit around & 69 & 2.46 & Mid-to-Low Range \\
\hline 23 & I am self-motivated & 69 & 2.46 & Mid-to-Low Range \\
\hline 24 & I enjoy public speaking and or speaking in class. & 64 & 2.29 & Mid-to-Low Range \\
\hline 25 & $\begin{array}{l}\text { I look for ways to acquire new skills that will enable me grow both as } \\
\text { a person and as a student }\end{array}$ & 89 & 3.18 & Mid- to-Upper Range \\
\hline 26 & I welcome change. I find it exciting & 90 & 3.21 & Mid- to-Upper Range \\
\hline 27 & I can adapt easily to change & 91 & 3.25 & Mid- to-Upper Range \\
\hline 28 & I am not timid about speaking in class and asking questions. & 68 & 2.43 & Mid-to-Low Range \\
\hline 29 & $\begin{array}{l}\text { I recognise that my health is important and I take the steps necessary } \\
\text { to maintain my health. }\end{array}$ & 112 & 4.0 & Mid- to-Upper Range \\
\hline 30 & I can work on projects independently. & 89 & 3.18 & Mid- to-Upper Range \\
\hline \multirow[t]{2}{*}{31} & I am able to get along and work well with other students & 87 & 3.11 & Mid-to-Upper Range \\
\hline & TOTAL SCORE & 2296 & 74.06 & Mid-to-Low Range \\
\hline
\end{tabular}

Table 1 reveals the average Personality Score of the Students to be 74.06 indicating that the students need to spend more time in developing their entrepreneurial skills before committing time and money to any business venture. Though in statements numbers $1,3,10,15,17,25-27$ and $29-31$ with a percentage of $35.48 \%$ of the Personality Skills Statements (11\% of 31 items), the scores of the students is in Mid-to-Upper Range. On the other hand, in statements numbers $2,4-14,16,18-24$, and 28 with a percentage of $64.52 \%$ of the Personality Skills items, the students' score is in Mid-to-Lower Range. It can be argued that the students have some attributes of an entrepreneur such as taking responsibilities for their actions, desire for skill acquisition, ability to embrace change, leadership and team working skills. They only need to ignite and develop the hidden skills and other qualities required to be a successful entrepreneur. This is in line with Granger \& Sterling (2012), that entrepreneurs develop skills to be successful. 
Table 2. Frequency distribution of future plan after graduation

\begin{tabular}{lll}
\hline VARIABLE & FREQUENCY & PERCENTAGE (\%) \\
\hline Enrol for higher degree programme. & 8 & 28.57 \\
Be self-Employed & 9 & 32.14 \\
Travel abroad & 4 & 14.29 \\
Secure job in a private/public organisation & 7 & 25.00 \\
TOTAL & & $\mathbf{1 0 0 . 0 0}$ \\
\hline
\end{tabular}

Table 2 shows that about one-third (32.14\%) of the students have plan to be self-employed after graduation, $28.57 \%$ want to further their academic career to a higher degree, $14.29 \%$ want to travel abroad for greener pasture while $25 \%$ want to secure job in either public/private organisation. The low percentage $(32.14 \%)$ of students desiring to be self-employed after graduation might be due to the environmental challenges in Nigeria society which inhibits or discourage small scale business especially people that are financially challenged. Though challenges such as unemployment crisis in the country can stimulate the students to be self-employed, Amabile et al. (1994) inform that this does not guarantee success. Consequently, the students have to develop high-level of self-efficacy in their capacity and be committed to the business for success (Chan et al., 1998; Hofstede, 1991; Morrison, 1998), however, self-efficacy can be enhanced through proper training (Carter \& Jones-Evans, 2000). According to Reynolds \& White, (1997), the fear of failure might be a constraint to entrepreneurship; therefore, other students who are not considering self-employment might be afraid of failure and unable to take risk despite the departmental effort to encourage job creation among the students. In general, all the students have to trigger their unique personality to interact with the challenging environments.

\section{Conclusion}

Though the department has introduced entrepreneurship topics in her curriculum to equip the students' with basic entrepreneurship knowledge, the students' personality trait to be self-employed is low, therefore, the University's Centre for Entrepreneurship has a significant role to play in strategic communication of entrepreneurship, conducting seminars, counselling and workshops on career development and entrepreneurship skills for the students. Secondly, Entrepreneurship Course should be introduced as a compulsory course for all students irrespective of their field of study. There should be collaboration between the department and the newly established College of Management Sciences to facilitate the skills needed for enterprise creation. The department should also identify successful entrepreneurs who can act as role models for the students and organise special lectures/workshops to trigger entrepreneurial spirit.

Having a University's degree is an investment opportunity for profitable returns; therefore, the students should be self-motivated to use their brain and mind to generate innovative business ideas such as improving on a product or service that is already in the market or create something new by adding value. The opportunity of being in the University is also to identify course-mates, friends or family members whom you share the same business vision, team work and pull resources together to form joint ventures.

The role of policy makers to support graduates to be self-employed especially at this massive unemployment crisis cannot be overemphasised. All over the world, policy makers recognise the importance of entrepreneurship to economic development especially among small and medium scale industries and committedly support this sector; Nigerian government should however intensify actions in favour of job creations and provide adequate and functional infrastructural facilities to enhance business start-up and success.

\section{References}

Abiodun, S. O. (2010). Analysis of Mismatch between Demand and Supply of Skills and University Graduate Unemployment in Nigeria. Unpublished M. Ed Dissertation, Lagos State University.

Adebayo, A. (1999). Youth Unemployment and National Directorate of Employment and Self-employment Programmes. Nigerian Journal of Economics and Social Sciences, 41(1), 81-102.

Akinyemi, S., Ofem, I. B., \& Ikuenomore, S. O. (2012). Graduate Turnout and Graduate Employment in Nigeria. International Journal of Humanities and Social Science, 2(14), 257-265. Retrieved from http://www.ijhssnet.com/journals/Vol_2_No_14_Special_Issue_July_2012/30.pdf

Amabile, T. M., Hill, K. G., Hennesey, B. A., \& Tighe, E. M. (1994). The Work Preference Inventory: Assessing Intrinsic and Extrinsic Motivational Orientations. Journal of Personality and Social Psychology, 66(5), 950-967. http://dx.doi.org/10.1037/0022-3514.66.5.950 
Amubode, A. A. (2009). Strategies for Economically Sustainable Resist Dyeing Industries in Abeokuta, Ogun State, Nigeria. Ph.D Thesis, Winchester School of Art, University of Southampton, U.K. Retrieved from http://eprints.soton.ac.uk/162155/1.hasCoversheetVersion/ADETOUN_AMUBODE_PHD_THESIS.pdf

Aromolaran, A. (1978). Modern Economic Analysis for "O" Level Students. Nigeria: CHAPTER Publishing Company. $\quad$ Retrieved from http://books.google.com.ng/books/about/Modern_Economic_Analysis.html?id=nbLRSAAACAAJ\&redir_e $\mathrm{sc}=\mathrm{y}$

Bakare, A. S. (2011). The Determinants of Urban Unemployment Crisis in Nigeria: An Econometric Analysis, Journal of Emerging Trends in Economics and Management Sciences, 2(3), 184-192. Retrieved from http://pdc-connection.ebscohost.com/c/articles/66422692/determinants-urban-unemployment-crisis-nigeriaeconometric-analysis

Benson, O. (2005). The Dynamics of Small Business Incubation Facilities in Fadama Areas of Ogun State in Nigeria: A Sustainable Anti-Poverty Device. Retrieved from www.socialedge.org/admin/Attachments/scale/why\%20you\%20shouldnt\%20scale\%20up/gcbe1.p_1.doc

Bourdieu, P. (1984). Distinction.A Social Critique of the Judgement of Taste. London: Routledge. Retrieved from $\mathrm{http} / / /$ esr.oxfordjournals.org/content/3/3/264.extract

Carter, S., \& Jones-Evans, D. (2000). Enterprise and Small Business: Principles, Practices and Policy. England: Pearson Education Limited.

Central Bank of Nigeria. (2008). Annual Report and Financial Statements for the Year ended $31^{\text {st }}$ December, 2000.

Chan, C. C., Gene Greene, P., \& Crick, A. (1998). Does Entrepreneurial Self Efficacy Distinguish Entrepreneurs From Managers? Journal of Small Business Venturing, 13(4), 295-316. http://dx.doi.org/10.1016/S0883-9026(97)00029-3

Chilee, R. (2013). Unemployment and the problem of the Nigerian graduate. Retrieved from http://murichie.wordpress.com/2012/05/23/unemployment-and-nigerian-graduates/ $\mathrm{http}: / / \mathrm{www}$.thescoopng.com/richard-chilee-unemployment-and-the-problem-of-the-nigerian-graduate/

Curran, J., \& Stanworth, J. (1989). Education and Training for Enterprise: Some Problems of Classification, Evaluation, Policy and Research, International Small Business Journal, 7(2), 110-128. http://dx.doi.org/10.1177/026624268900700201

Deakins, D. (1996). Entrepreneurship and Small Firms. England: McGraw-Hill.

Deakins, D., \& Freel, M. (2009). Entrepreneurship and Small Firms (5th ed.). United Kingdom: McGraw Hill Education.

Deci, E. L. (1992). The Relation of Interest to the Motivation of Behaviour: a Self Determination Theory Perspective. In K. A. Renniger, S. Hidi, \& A. Krapp (Eds.), The Role of Interest in Learning and Development (pp. 43-70). Hillsdale, NJ: Erlbaum.

Egbuna, E. N. (2001). Food Production: An African Challenge. Central Bank of Nigeria Economic and Financial Review, 39(1), 13.

Fajana, S. (2000). Functioning of the Nigerian Labour Market. Lagos: Labonfin and Company.

Fnae, K. A., Adeniji, I. A., \& Adu, E. O. (2008). Graduate Unemployment in Nigeria: A Blind Spot in the Nation's Educational System. The African Symposium, 8(2), 77-96.

Granger, M. M., \& Sterling, T. M. (2012). Fashion Entrepreneurship: Retail Business Planning (2nd ed.). USA: Fairchild Publications, Inc.

Hofstede, G. (1991). Cultures and Organizations: Software of the Mind. London: McGraw-Hill.

Kakwagh, V. V., \& Ikwuba, A. (2010). Youth Unemployment in Nigeria: Causes and Related Issues. Canadian Social Science, 6(4), 231-237. Retrieved from www.cscanada.net/index.php/css/article/download/1097/1116

Kirzner, I. (1973). Competition and Entrepreneurship. Chicago, IL: University of Chicago Press.

Kodithuwakku, S. S., \& Rosa, P. (2002). The Entrepreneurial Process and Economic Success in a Constrained $\begin{array}{lllll}\text { Environment. Journal of Business } & \text { Venturing, }\end{array}$ http://dx.doi.org/10.1016/S0883-9026(01)00074-X 
Krueger, N. J., \& Dickson, P. R. (1994). How Believing in Ourselves Increases Risk Taking: Perceived Self-Efficacy and Opportunity Recognition. Decision Sciences, 25(3), 385-400. http://dx.doi.org/10.1111/j.1540-5915.1994.tb01849.x

McClelland, D. C., \& Winter, D. G. (1969). Motivating Economic Achievement. New York: Free Press.

Minner, J. B., Smith, N. R., \& Bracker, J. S. (1989). Role of Entrepreneurial Task Motivation in the Growth of Technologically Innovative Firms. Journal of Applied Psychology, 74(4), 554-556. http://dx.doi.org/10.1037/0021-9010.74.4.554

Morrison, A. (1998). Entrepreneurship: An International Perspective. Oxford: Butter worth-Heinemann.

Okafor, E. E. (2011). Youth Unemployment and Implications for Stability of Democracy in Nigeria. Journal of Sustainable Development in Africa, 13(1), 358-373. Retrieved from http://www.jsd-africa.com/Jsda/V13No1_Spring2011_A/PDF/Youth\%20Unemployment\%20and\%20Implic ations\%20For\%20Stability\%20of\%20Democracy\%20\%28Okafor\%29.pdf

Okoye-Nebo, C., Kenneth, I., \& Ugochukwu, U. (2014). Youth Unemployment and Entrepreneurship Development: Challenges And Prospects In Nigeria. Arabian Journal of Business and Management Review, 4(4), 20-35. Retrieved from http://www.arabianjbmr.com/pdfs/KD_VOL_4_4/3.pdf

Oladele, P. O., Akeke, I., \& Oladunjoye, O. (2011). Entrepreneurship Development: A Panacea for Unemployment Reduction in Nigeria. Journal of Emerging Trends in Economics and Management Sciences, 2(4), 251-256.

Olajire, A. (2004). Small Scale Enterprises as Investment Opportunities for Visual Artists. Journal of the Society of Nigerian Artist, 4, 50-51.

Oyelola, O. T., Ajiboshin, I. O., Raimi, L., Raheem, S., \& Igwe, C. N. (2013). Entrepreneurship for Sustainable Economic Growth in Nigeria. Journal of Sustainable Development Studies, 2(2), 197-215. Retrieved from http://infinitypress.info/index.php/jsds/article/viewFile/67/59

Pearce, I. (1980). Reforms of Entrepreneurs to Serve Public Policy, The Prime Mover of Progress: The Entrepreneur in Capitalism and Socialism. London: The Institute of Economic Affairs.

Raffo, C., Lovatt, A., Banks, M., \& O’Connor, J. (2000). Teaching and Learning Entrepreneurship for Micro and Small Businesses in the Cultural Industries Sector. Education and Training, 42(6), 356-365. http://dx.doi.org/10.1108/00400910010353653

Raffo, C., Lovatt, A., Banks, M., \& O’Connor, J. (2000). Teaching and Learning Entrepreneurship for Micro and Small Businesses in the Cultural Industries Sector. Education and Training, 42(6), 356-365. http://dx.doi.org/10.1108/00400910010353653

Raimi, L., \& Adeleke, I. (2010). Using Entrepreneurship Development and Corporate Social Responsibility as Strategies for Conflict Resolution in the Niger-Delta region in Nigeria. A Paper presented at the 34th Annual SPE International Technical Conference and Exhibition inTinapa Calabar, Cross Rivers State. http://dx.doi.org/10.2118/140676-ms

Reynolds, P., \& White, S. (1997). The Entrepreneurial Process: Economic Growth, Men, Women and Minorities. Westport, CT: Quorum.

Saylor, M. (1987). Home based enterprise development and craft marketing. Proceedings of International Rural Entrepreneurship Symposium (pp. 57-70). Economic Research Service, USDA, Knoxville, Tennessee.

Scase, R., \& Goffe, R. (1980). The Real World of the Small Business owner. London: Croom Helm.

Schumpeter, J. A. (1934). The theory of economic development. Cambridge, MA: Harvard University Press.

Shane, S., \& Venkataraman, S. (2000). The promise of entrepreneurship as a field of research. Academy of Management Review, 25(1), 217-226. http://dx.doi.org/10.5465/amr.2000.2791611

Spring, A., \& McDade, B. E. (2003). African Entrepreneurship: Theory and Reality. Florida, University Press of Florida. Retrieved from http://nersp.nerdc.ufl.edu/ upf

Timmons, J. A. (1999). New Venture Creation, Entrepreneurship for the $21^{\text {st }}$ Century. Boston: Irwin McGraw-Hill.

Ukwu, C. (2013). The Need to reconcile unemployment figures in Nigeria. Retrieved from http://leadership.ng/news/280713/need-reconcile-unemployment-figures-nigeria 


\section{Copyrights}

Copyright for this article is retained by the author(s), with first publication rights granted to the journal.

This is an open-access article distributed under the terms and conditions of the Creative Commons Attribution license (http://creativecommons.org/licenses/by/3.0/). 